\title{
The Effect of Distal Ureteral Stone Size Measurements on Spontaneous Passage
}

Distal Üreter Taşlarının Boyut Ölçümlerinin Spontan Pasaj Üzerine Etkisi

\author{
(D) Şakir Ongün1, (D) Murat Dursun² \\ 1 Balıkesir University Faculty of Medicine, Department of Urology, Balıkesir, Turkiye \\ 2Malatya Local Health Authority Malatya Training and Research Hospital, Clinic of Urology, Malatya, Turkiye
}

\section{What's known on the subject? and What does the study add?}

Ureteral stone size, defined as the longest value measured on computed tomography, is used to predict spontaneous passage, and axial sections are often utilized for this measurement. However, the largest measurement of cylindrical ureteral stones is obtained by assessing the crania-caudal dimension. In this study, it was demonstrated that stone length measurement in the coronal plane should be considered as a priority when planning the treatment for ureteral stones.

\begin{abstract}
Objective: To investigate the relationship of spontaneous ureteral stone passage with stone size (width-length) and area.

Materials and Methods: Patients who presented to the urology outpatient clinic with acute renal colic between January and December 2016 and were found to have a distal ureteral stone of $10 \mathrm{~mm}$ or smaller on unenhanced computed tomography (CT) were retrospectively evaluated. Using the CT images, the size of the stones was measured and the data of the patients were compared in terms of spontaneous passage status.

Results: A total of 245 patients were included in the study. The mean stone size on the axial plane and coronal plane was $4.72 \pm 1.55 \mathrm{~mm}$ and $4.75 \pm 1.84 \mathrm{~mm}$, respectively and the spontaneous passage rate was $77.6 \%$. In logistic regression analysis, the most important factor in predicting spontaneous passage was the stone size on coronal measurement $(p=0.020)$. The spontaneous passage rate was $70.8 \%$ in cases where the stone size on the axial plane was the same as or larger than on the coronal plane, 56.2\% when the size on the the coronal plane was $1 \mathrm{~mm}$ greater than on the axial plane, and 34.7\% when the stone size on the the coronal plane was $2 \mathrm{~mm}$ or more than $2 \mathrm{~mm}$ greater than on the axial size. Chi-square analysis revealed that the difference between spontaneous passage rates was statistically significant $(p=0.001)$.

Conclusion: When planning treatment for ureteral stones, the length of the stone in coronal measurement should be considered as a priority. It should be remembered that the probability of spontaneous passage is significantly low, especially if the length of the stone is $2 \mathrm{~mm}$ or more than $2 \mathrm{~mm}$ greater than its width.
\end{abstract}

Keywords: Spontaneous passage, Computerized tomography, Ureteral stone

Öz

Amaç: Distal üreter taşlarının spontan pasajı ile taş boyut ölçümleri (en-boy) ve taş alanı arasındaki ilişkiyi araştırmayı amaçladık.

Gereç ve Yöntem: Ocak 2016 ile Aralık 2016 tarihleri arasında akut renal kolik ile üroloji polikliğine başvuran ve kontrastsız bilgisayarlı tomografide (BT) $10 \mathrm{~mm}$ ve daha küçük distal üreter taşı saptanan hastaların bilgileri retrospektif olarak değerlendirildi. BT görüntüleri kullanılarak taş boyutları hesaplanarak spontan pasaj durumuna göre hastaların verileri karşılaştırıldı.

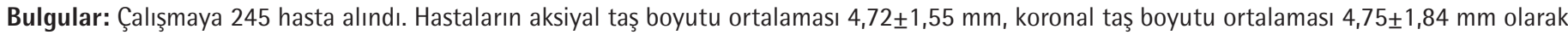

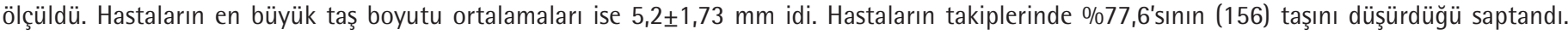
Yapılan logistik regresyon analizinde spontan pasajı öngörmede en etkili faktörün taşın koronal ölçümünün olduğu saptanmıştır ( $p=0,020)$. Hastaların spontan pasaj oranları aksiyal boyutun koronal boyut ile aynı veya daha büyük olduğu durumlarda \%70,8 olarak saptandı. Koronal boyut ile aksiyal

Correspondence: Şakir Ongün MD, Balıkesir University Faculty of Medicine, Departman of Urology, Balıkesir, Turkiye

Phone: +90 5069307672 E-mail: sakirongun@hotmail.com ORCID-ID: orcid.org/0000-0002-8253-4086

Received: 17.10 .2018

Accepted: 25.11 .2018

Cite this article as: Ongün Ş, Dursun M. The Effect of Distal Ureteral Stone Size Measurements on Spontaneous Passage. J Urol Surg 2019;6(2):139-143.

๑Copyright 2019 by the Association of Urological Surgery / Journal of Urological Surgery published by Galenos Publishing House. 
boyuttan $1 \mathrm{~mm}$ daha büyük olduğu durumlarda spontan pasaj \%56,2, $2 \mathrm{~mm}$ ve daha büyük olduğu durumlarda ise \%34,7 olarak bulundu. Yapılan ki-kare analizinde spontan pasaj oranları arasındaki farkın istatistiksel olarak anlamlı olduğu saptandı $(p=0,001)$.

Sonuç: Üreter taşlarında tedavi planı yapılırken taşın koronal ölçümdeki boyu (uzunluğu) öncelikli olarak dikkate alınmalıdır. Özellikle taşı boyu eninden $2 \mathrm{~mm}$ ve daha fazla ise spontan pasaj olasığının ciddi oranda düşük olduğu akılda bulundurulmalıdır.

Anahtar Kelimeler: Spontan pasaj, Bilgisayarlı tomografi, Üreter taşı

\section{Introduction}

The incidence of urinary stone disease varies between $2 \%$ and $20 \%$ and the lifetime prevalence of this disease is $5-12 \%(1,2)$. Ureteral stones constitute $20 \%$ of all urinary system stones (3).

Extracorporeal shock wave lithotripsy, ureteroscopic lithotripsy or laparoscopic ureterolithotomy can be used for the treatment of ureteral stones. The size and location of the stone is a determinant factor in the decision-making process. Stones $\leq 4 \mathrm{~mm}$ in the distal ureter are expelled spontaneously with a probability of $95 \%$ (4). This rate is $47 \%$ for those between 5 $\mathrm{mm}$ and $10 \mathrm{~mm}$ (4). These high rates of spontaneous passage encourage urologists to adopt a more conservative approach for the treatment of distal ureteral stones, however, conservative monitoring can cause discomfort and complications, such as infection, hydronephrosis, and impaired renal function (5).

The most common predictors for the passage of the stone spontaneously are stone size and location (6). In meta-analyses reporting spontaneous passage rates, the size of ureteral stone is usually the longest measurement in the axial section or the largest measurement of the stone (4). Ureteral stone size is defined as the longest value measured on computed tomography (CT), and axial sections are often used in this measurement $(7,8)$. However, the largest measurement of cylindrical ureteral stones is obtained by assessing the crania-caudal dimension. With the widespread use of multidetector CTs, coronal reformatted images have been a part of routine use, and as a result, there has been a change in the measurement of the maximum size of ureteral stones $(9,10)$. It has been shown that stone area and stone volume are determinants in predicting spontaneous passage $(11,12)$.

In this research, we explored the correlation of spontaneous passage with stone size (width-length) and area in distal ureteral stones.

\section{Materials and Methods}

Patients who presented to the urology outpatient clinic with acute renal colic in January-December 2016, with $10 \mathrm{~mm}$ or smaller distal ureteral stones on unenhanced CT were retrospectively evaluated. Patients, who had no surgical intervention after the first diagnosis and attended follow-up visits at weeks 4 to 8 , were included in the study. Patients younger than 18 years of age, with a non-radiopaque stone, urinary system infection or solitary kidney, multiple stones, those who had not started medical expulsive therapy, and those without follow-up data were excluded from the study.

The CT images were taken without the injection of oral or intravenous contrast material with the patients holding their breath in the supine position. The key areas imaged were the kidneys and the bladder, and the interslice gap was $1 \mathrm{~mm}$ (MX8000; Philips, Eindhoven, the Netherlands). From the raw data obtained from the CT scanner, axial-sagittal and coronal reconstruction images with a 1-mm thickness were analyzed. The CT images were then transferred to an extended workstation in the Digital Imaging and Communications in Medicine (DICOM) format (2-GHz Pentium processor with 2014 MB of randomaccess memory) for postprocessing. Using the CT images, the maximum width and length of the stones were measured in axial and coronal sections, respectively. The measurements were performed by the urologists in this study. The largest diameter was defined as the measured largest diameter in axial and coronal sections. The stone area was calculated by multiplying the maximum axial dimension by and the maximum coronal dimension. The stones located above and below the pelvic brim were classified as proximal and distal, respectively. We also performed an initial kidney, ureter, and bladder X-ray (KUB) in all patients to make sure that the stones were visible on KUB. The patients were prescribed oral tamsulosin $0.4 \mathrm{mg}$ daily for medical expulsive therapy, and we advised all the patients to increase fluid intake and do exercise.

At the follow-up visit, the absence of patient complaints and the patients reporting to have witnessed stone expulsion (the time that patients reporting to have witnessed stone explusion were accepted as the spontaneous passage time), and/or a KUB revealing no stone were accepted as spontaneous passage. The study was conducted in accordance with the principles of the Declaration of Helsinki and informed consent was taken.

\section{Statistical Analysis}

Statistical analysis of the data was performed using the SPSS software v. 22.0 (IBM Corp., Armonk, NY). The continuous variables were expressed as mean \pm standard deviation and student's t-test was used for comparison. To determine the differences in the prediction of spontaneous passage between axial and coronal plane measurements; i.e., the relationship 
between the time to stone passage and stone size, chi-square or two-tailed Fisher's exact tests were used. To identify the predictors of stone passage, binary logistic regression analyses were performed. The results of the regression analysis were obtained as the odds ratio and 95\% confidence interval. A p value of less than or equal to 0.05 was considered statistically significant.

\section{Results}

A total of 245 patients, 75 females and 170 males, were included in the study. The mean age of the patients was $36.97 \pm 11.69$ (1876) years. The mean stone size on axial plane was $4.72 \pm 1.55$ $\mathrm{mm}$ and the mean stone size on coronal plane was $4.75 \pm 1.84$ $\mathrm{mm}$. The largest stone size was determined as $5.2 \pm 1.73 \mathrm{~mm}$, and the mean area of the stone was $24.65 \pm 17.91 \mathrm{~mm}^{2}$. The average anteroposterior (AP) pelvic diameter was $15.18 \pm 6.06 \mathrm{~mm}$; the stone was in the right side in 140 patients and in the left in 105.

The stone passed spontaneously in $77.6 \%$ of patients $(n=156)$ with the mean spontaneous passage being 2.1 weeks. Spontaneous passage rates were $84.9 \%(113 / 133)$ for stones of $<5 \mathrm{~mm}$ on axial measurement, and $85.9 \%$ (117/137) for those of $<5 \mathrm{~mm}$ on coronal measurement. For stones measured to be $5-10 \mathrm{~mm}$ in the axial and coronal sections, the rate of spontaneous passage was $38.3 \%$ (43/112) and $36.1 \%$ (39/108), respectively. Considering the largest stone diameter measured on coronal and axial sections, the spontaneous passage rates were $88.1 \%$ (96/109) for $<5 \mathrm{~mm}$ stones, and $44.1 \%$ (60/136) for 5-10 $\mathrm{mm}$ stones.

When the data of the patients with and without spontaneous stone passage were compared, it was determined that the stone size, area and AP pelvic diameter in the former group were statistically significantly smaller than those in the latter group $(p<0.001)$. The results of stone size, area and AP pelvic diameter according to spontaneous passage status of patients are shown in Table 1.

Moreover, binary logistic regression analysis was performed to identify the value of stone sizes (axial and coronal), the largest stone size, AP pelvic diameter and stone area for passage of

Table 1. The results of stone size, area and anteroposterior pelvic diameter according to spontaneous passage status

\begin{tabular}{llll}
\hline & $\begin{array}{l}\text { Spontaneous } \\
\text { passage (+) }\end{array}$ & $\begin{array}{l}\text { Spontaneous } \\
\text { passage (-) }\end{array}$ & $\mathbf{p}$ \\
\hline Axial & $4.1 \pm 1.1$ & $5.7 \pm 1.6$ & $<0.001$ \\
\hline Coronal & $3.9 \pm 1.2$ & $6.1 \pm 1.8$ & $<0.001$ \\
\hline Largest stone & $4.47 \pm 1.26$ & $6.47 \pm 1.70$ & $<0.001$ \\
\hline Stone area & $17.33 \pm 10.64$ & $37.48 \pm 20.70$ & $<0.001$ \\
\hline AP pelvic diameter & $14.10 \pm 4.46$ & $17.09 \pm 7.81$ & $<0.001$ \\
\hline AP: Anteroposterior & & &
\end{tabular}

the stone spontaneously. Coronal stone size was independently correlated with spontaneous passage ( $p=0.020)$. Table 2 presents the results of logistic regression analysis.

Spontaneous passage rates were calculated as $70.8 \%$ in cases where the stone size on the axial plane was the same as or greater than on the the coronal plane; $56.2 \%$ in those where the coronal size was $1 \mathrm{~mm}$ greater than the axial size, and 34.7 in those where the coronal size was $2 \mathrm{~mm}$ or more than $2 \mathrm{~mm}$ greater than the axial size. The chi-square analysis revealed that the difference in spontaneous passage rates according to the difference between axial and coronal measurements was statistically significant $(p=0.001)$. Table 3 shows the rates of spontaneous passage according to the difference between axial and coronal plane measurements.

When time to passage and stone dimensions of stone-bearing patients were compared, no statistically significant result was found. In Table 4, the time to spontaneous passage according to the stone size was compared.

No statistically significant relationship was found between the stone passing time and stone size of the patients. Table 4 presents the comparative results of spontaneous passage times by stone size.

\section{Discussion}

There are various options for the treatment of ureteral stones. The mutual request is to treat the disease without surgery as much as possible and at the same time to minimize the possibility of development of any complication. To achieve

Table 2. Predictive value of stone size, area and anteroposterior pelvic diameter for spontaneous passage on binary logistic regression analysis

\begin{tabular}{llllll}
\hline & \multirow{2}{*}{$\mathbf{p}$} & Wald & \multicolumn{2}{l}{$\mathbf{9 5} \mathrm{Cl}$} & \\
\cline { 4 - 6 } & & & OR & Lower & Upper \\
\hline Axial & 0.059 & 3.553 & 0.364 & 0.128 & 1.041 \\
\hline Coronal & 0.020 & 5.384 & 0.278 & 0.095 & 0.820 \\
\hline Largest stone & 0.580 & 0.306 & 1.347 & 0.469 & 3.870 \\
\hline Stone area & 0.147 & 2.107 & 1.102 & 0.967 & 1.256 \\
\hline AP pelvic diameter & 0.550 & 0.358 & 0.983 & 0.928 & 1.040 \\
\hline
\end{tabular}

AP: Anteroposterior, Nagelkerke $\left(R^{2}=0.428\right)$

Table 3. The rates of spontaneous passage according to the difference between axial and coronal plane measurements

\begin{tabular}{lllll}
\hline & $\begin{array}{l}\text { Axial } \geq \\
\text { Coronal }\end{array}$ & $\begin{array}{l}\text { Coronal - } \\
\text { Axial =1 }\end{array}$ & $\begin{array}{l}\text { Coronal - } \\
\text { Axial } \geq 2\end{array}$ & $\mathbf{p}$ \\
\cline { 1 - 4 } $\begin{array}{l}\text { Spontaneous } \\
\text { passage (-) }\end{array}$ & $29.1 \%(46)$ & $43.7 \%(28)$ & $65.2 \%(15)$ \\
\cline { 1 - 2 } $\begin{array}{l}\text { Spontaneous } \\
\text { passage (+) }\end{array}$ & $70.8 \%(112)$ & $56.2 \%(36)$ & $34.7 \%(8)$ & \\
& & & &
\end{tabular}


Table 4. The comparative results of time to spontaneous passage by stone size

\begin{tabular}{|c|c|c|c|c|c|c|}
\hline & \multicolumn{5}{|c|}{ Spontaneous passage time } & \multirow[b]{2}{*}{$\mathbf{p}$} \\
\hline & Week 1 & Week 2 & Week 3 & Week 4 & $>4$ weeks & \\
\hline Axial size & $4.09 \pm 1.34$ & $4.11 \pm 1.13$ & $4.00 \pm 0.72$ & $4.35 \pm 0.99$ & $5.00 \pm 1.41$ & 0.710 \\
\hline Largest size & $4.37 \pm 1.39$ & $4.45 \pm 1.21$ & $4.25 \pm 0.96$ & $5.00 \pm 1.36$ & $5.00 \pm 1.41$ & 0.377 \\
\hline
\end{tabular}

this, it is crucial to have an insight into which stones are more likely to be spontaneously passed and which require surgical intervention.

The two most important factors in predicting spontaneous ureteral stone passage are stone size and location. In metaanalyses reporting spontaneous passage rates, the size of a ureteral stone is usually accepted as the widest measurement on the axial plane or the largest measurement of the stone (4). In previous studies, spontaneous passage rates were found to be $95 \%$ in distal ureteral stones of $<5 \mathrm{~mm}$, and $47 \%$ for those of 5-10 $\mathrm{mm}$ (4). In addition, Coll et al. (13) reported the spontaneous passage rate of 48\%,60\%, and 75\% for proximal, middle and distal ureteral tones, respectively. Also Jenderberg et al. (14) reported that the spontaneous passage rates in 20 weeks for distal ureteral stones was; $97 \%$ in $0-2.4 \mathrm{~mm}, 99 \%$ in 2.5-3.4 $\mathrm{mm}, 83 \%$ in $3.5-4.4 \mathrm{~mm}, 89 \%$ in $4.5-5.4 \mathrm{~mm}, 57 \%$ in $5.5-6.4$ $\mathrm{mm}$ and $33 \%$ in $>6.4 \mathrm{~mm}$.

In the current study, the stones spontaneously passed in $77.6 \%$ of the patients $(n=156)$. The spontaneous passage rate was $84.9 \%$ and $85.9 \%$ for stones smaller than $5 \mathrm{~mm}$ according to axial and coronal measurements, respectively. For stones measured as 5-10 $\mathrm{mm}$ on axial and coronal planes, spontaneous passage rate was calculated as $38.3 \%$ and $36.1 \%$, respectively. Lastly, according to the largest size of stones in both planes, spontaneous passage rate was found to be $88.1 \%$ for stones of $<5 \mathrm{~mm}$ and $44.1 \%$ for those of 5-10 mm. Although the results of spontaneous passage for axial and coronal measurements are similar, there is a clear decrease in spontaneous passage rate when the size of the stone increases from $4 \mathrm{~mm}$ to $5 \mathrm{~mm}$. In addition, if the stone shape is spherical, then the dimensions on the axial and coronal planes will be similar, however, in cases of cylindrical stones, different values can be obtained. For example, a stone with the widest axial measurement of $3 \mathrm{~mm}$ may have the longest coronal length of $7 \mathrm{~mm}$, or vice versa. In such cases, it is important to determine which measurement to consider in the decision-making process regarding treatment.

Metser et al. (15) compared ureteral stone dimensions on axial and coronal planes and found that the axial measurement underestimated stone size by $13 \%$ than the coronal measurement. Similarly, in another study, Nazim et al. (16) determined that compared to the coronal measurement, the axial measurement underestimated stone size by $20 \%$ for all stones and by $17 \%$ for those that were spontaneously passed (16). In the current study, we also found that the coronal measurements estimated stone size to be greater than the axial measurements in 35\% of patients. An even more remarkable point is that when the axial dimension was the same as or greater than the coronal dimension, spontaneous passage rate was $70.8 \%$, but in cases where the coronal measurement was $1 \mathrm{~mm}$ or $\geq 2 \mathrm{~mm}$ greater than the axial measurement, the spontaneous passage rates were found to be smaller (56.2\% and 34.7\%, respectively). As also suggested by Lee et al. (17), we consider that spontaneous passage is more difficult for stones with a larger diameter on coronal plane due to more contact with ureteral mucosa resulting in increased inflammation, edema, and friction force.

In this study, although stone size and stone area measurements produced statistically significant results in predicting spontaneous passage, the logistic regression analysis revealed that the most effective predictor was the coronal measurement $(p=0.020)$. In cases where the difference between the dimensions on coronal and axial planes increased in favor of the former, the rate of spontaneous passage decreased from $70.8 \%$ to $34.7 \%$ $(p=0.001)$. Similarly, Kadihasanoglu et al. (18) reported that the possibility of spontaneous passage was significantly reduced in patients for whom the coronal measurement was $\geq 2 \mathrm{~mm}$ greater than the axial measurement.

The different spontaneous passage rates obtained from the axial and coronal plane measurements suggest that stone area may also have an effect. Demehri et al. (11) found that stone area was an important parameter in predicting spontaneous passage in patients with a stone size of 5-10 $\mathrm{mm}$. In another study investigating stone volume, Zorba et al. (12) reported no statistically significant result for $\leq 7 \mathrm{~mm}$ stones, but the authors noted that stones larger than $7 \mathrm{~mm}$ were less likely to be spontaneously passed if their volume was also greater than $52 \mathrm{~mm}^{3}$. In the current study, we determined that the rate of spontaneous passage was statistically significantly increased as the stone area was reduced, however, according to multivariate analyses, stone area did not have a significant predictive value for spontaneous stone passage. We estimate that the reason is the increased contact with ureteral mucosa as we mentioned previously.

It is always difficult to decide how long to wait for spontaneous stone passage. If intervention is not undertaken after four 
to six weeks of no spontaneous passage, the possibility of kidney damage is increased $(19,20)$. It has been reported that spontaneous passage occurs, on average, within 1.6 weeks for $<4 \mathrm{~mm}$ stones and 2.8 weeks for $4-6 \mathrm{~mm}$ stones (21). In this study, we did not observe a statistically significant result when we compared stone size and spontaneous passage time.

\section{Study Limitations}

Due to the retrospective nature of this study, the patients who did not receive medical expulsive therapy and those who did not attend the follow-up visits had to be excluded from the study. Another limitation concerned the relatively small number of patients.

\section{Conclusion}

Advances in imaging methods and development of multiplanar reformatted images enabled coronal reconstruction, in which ureter stone size can be calculated on the coronal plane. For planning treatment, coronal measurements provide more reliable results in predicting spontaneous passage compared to axial measurements. It should be noted that the probability of spontaneous passage is significantly low, especially if the coronal measurement is $\geq 2 \mathrm{~mm}$ larger than the axial measurement.

\section{Ethics}

Ethics Committee Approval: Retrospective study.

Informed Consent: It was taken.

Peer-review: Externally peer-reviewed.

\section{Authorship Contributions}

Concept: S.O., M.D., Design: S.O., M.D., Data Collection and/ or Processing: S.O., M.D., Analysis and/or Interpretation: S.O., Literature Research: S.O., M.D., Writing: S.O.

Conflict of Interest: No conflict of interest was declared by the authors.

Financial Disclosure: The authors declared that this study received no financial support.

\section{References}

1. Picozzi SC, Marenghi C, Casellato S, Ricci C, Gaeta M, Carmignani L. Management of ureteral calculi and medical expulsive therapy in emergency departments. J Emerg Trauma Shock 2011;4:70-76.

2. Sfoungaristos $S$, Kavouras A, Katafigiotis I, Perimenis P. Role of white blood cell and neutrophil counts in predicting spontaneous stone passage in patients with renal colic. BJU Int 2012;110:E339-E345.
3. Gravas S, Tzortzis V, Karatzas A, Oeconomou A, Melekos MD. The use of tamsulosin as adjunctive treatment after ESWL in patients with distal ureteral stone: do we really need it? Results from a randomised study. Urol Res 2007;35:231-235.

4. Preminger GM, Tiselius HG, Assimos DG, Alken P, Buck C, Gallucci M, Knoll T, Lingeman JE, Nakada SY, Pearle MS, Sarica K, Türk C, Wolf JS Jr; EAU/ AUA Nephrolithiasis Guideline Panel. 2007 guideline for the management of ureteral calculi. J Urol 2007;178:2418-2434.

5. Ueno A, Kawamura T, Ogawa A, Takayasu H. Relation of spontaneous passage of ureteral calculi to size. Urology 1977;10:544-546.

6. Skolarikos A, Laguna MP, Alivizatos G, Kural AR, de la Rosette JJ. The role for active monitoring in urinary stones: a systematic review. J Endourol 2010;24:923-930.

7. Kampa RJ, Ghani KR, Wahed S, Patel U, Anson KM. Size matters: A survey of how urinary-tract stones are measured in the UK. J Endourol 2005;19:856860.

8. Zagoria RJ, Khatod EG, Chen MYM. Abdominal radiography after CT reveals urinary calculi: A method to predict usefulness of abdominal radiography on the basis of size and CT attenuation of calculi. AJR Am J Roentgenol 2001;176:1117-1122.

9. Berkovitz N, Simanovsky N, Katz R, Salama S, Hiller N. Coronal reconstruction of unenhanced abdominal CT for correct ureteral stone size classification. Eur Radiol 2010;20:1047-1051.

10. Nadler RB, Stern JA, Kimm S, Hoff $F$, Rademaker AW. Coronal imaging to assess urinary tract stone size. J Urol 2004;172:962-964.

11. Demehri S, Steigner ML, Sodickson AD, Houseman EA, Rybicki FJ, Silverman SG. CT-Based Determination of Maximum Ureteral Stone Area: A Predictor of Spontaneous Passage. AJR Am J Roentgenol 2012;198:603-608.

12. Zorba OÜ, Ogullar S, Yazar S, Akca G. CT-Based Determination of Ureteral Stone Volume: A Predictor of Spontaneous Passage. J Endourol 2016;30:3236.

13. Coll DM, Varanelli MJ, Smith RC. Relationship of spontaneous passage of ureteral calculi to stone size and location as revealed by unenhanced helical CT. AJR Am J Roentgenol 2002;178:101-103.

14. Jendeberg J, Geijer H, Alshamari M, Cierzniak B, Lidén M. Size matters: The width and location of a ureteral stone accurately predict the chance of spontaneous passage. Eur Radiol 2017;27:4775-4785.

15. Metser U, Ghai S, Ong YY, Lockwood G, Radomski SB. Assessment of urinary tract calculi with 64-MDCT: the axial versus coronal plane. AJR Am J Roentgenol 2009;192:1509-1513.

16. Nazim SM, Ather MH, Khan N. Measurement of ureteric stone diameter in different planes on multidetector computed tomography--impact on the clinical decision making. Urology 2014;83:288-292

17. Lee SR, Jeon HG, Park DS, Choi YD. Longitudinal stone diameter on coronal reconstruction of computed tomography as a predictor of ureteral stone expulsion in medical expulsive therapy. Urology 2012;80:784-789.

18. Kadihasanoglu M, Marien $T$, Miller NL. Ureteral Stone Diameter on Computerize Tomography Coronal Reconstructions Is Clinically Important and Under-reported. Urology 2017;102:54-60.

19. Miller OF, Kane CJ. Time to stone passage for observed ureteral calculi: a guide for patient education. J Urol 1999;162:688-690

20. Ibrahim Al, Shetty SD, Awad RM, Patel KP. Prognostic factors in the conservative treatment of ureteric stones. Br J Urol 1991;67:358-361.

21. Hubner WA, Irby P, Stoller ML. Natural history and current concepts for the treatment of small ureteral calculi. Eur Urol 1993;24:172-176. 